DOI: $10.3938 /$ PhiT. 26. 032

\section{Design and Discovery of Super Functional Materials: Methods and Applications}

In-Ho LEE, Jooyoung LEE and K. J. CHANG

The aim of this article is to define and unify the field of super functional materials design and discovery through the global optimization method in a reasonably self-contained exposition. Design and discovery examples include the materials for solar cell and light-emitting-diode. In addition, carbon-based topological material for a high mobility is also designed through the systematic crystal structure search.

\section{들어가는 글}

원하는 소재 물성을 극대화시키고자 하는 아이디어는 응집물 질 이론 연구에서 매우 자연스러운 것이다. 예를 들어, 어떻게 하면 값싼 소재를 이용하여 최고의 태양전지 효율을 가지는 반 도체를 얻을 수 있을까? 또는 어떻게 하면 최고의 열전 성능을

\section{저자약력}

이인호 박사는 한국과학기술원(물리학과) 이학박사로서 Univ. of Illinois at Urbana-Champaign(Beckman Institute for Advanced Science and Technology, Materials Research Laboratory) 박사 후 과정 그리고 고 등과학원(물리학부) 리서차-펠로우를 거쳐 한국표준과학연구원 선임 연구원 (2001-2005), 책임 연구원(2005-)으로 재직 중이다. 고등과학원 인실리코 단백질과학 연구단 서브그룹리더(2009-2017) 그리고 과학기술연합대학원 대학교(UST) 나노계측학과 겸임교수(2013-현재)로서 활동하고 있다. (ihlee@kriss.re.kr)

이주영 교수는 서울대학교 물리학과를 졸업하고, 1990년에 Brown University에서 상전이 현상의 수치적 접근법이란 주제로 박사학위를 취득했다. Argonne National Lab(1990-1992), Florida State Univ.(1992-1994) 에서 박사후 연구원을, Mt. Sinai School of Medicine(1994-1997), Cornell University(1997-2000)에서 연구원으로 지냈고, 2000년부터 고 등과학원 계산과학부 교수로 재직 중이다.(jlee@kias.re.kr)

장기주 교수는 1986년 미국 UC Berkeley 대학에서 물리학 박사학위를 취 득하였으며, 미국 로렌스 버클리 연구소 및 제록스 팔로알토 연구소에서 박 사후 연구원을 거친 후 1989년부터 한국과학기술원 물리학과 교수로 재직 중이다.(kjchang@kaist.ac.kr)
The inverse band-structure problem of finding an atomic configuration with given electronic properties

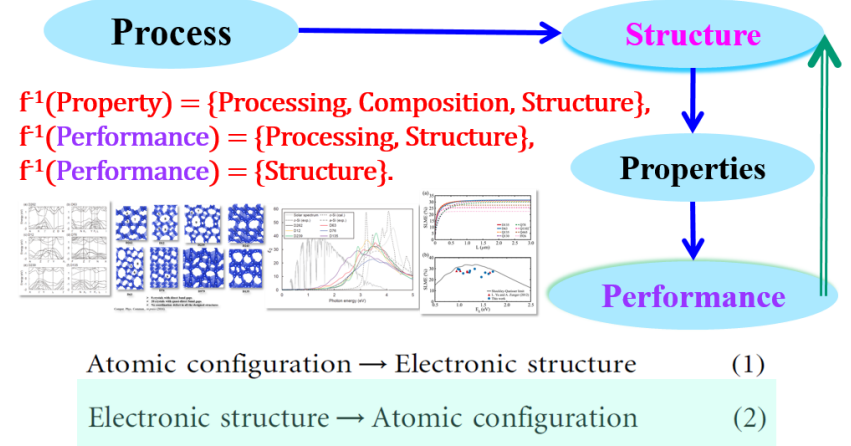

Fig. 1. The understanding of processing, structure, property (performance) relationships is called the materials paradigm. Specific material properties are initially assigned and target materials are subsequently searched for.

가지는 친환경 소재를 만들어 낼 수 있을까? 사실은 소재 공정, 구조, 물성, 성능지수 등을 종합적으로 특성화하는 연구를 수행 해야한다. 하지만, 너무나도 복잡한 소재 공정을 잠시 고려하지 않고 단순히 결정구조와 성능지수를 간단한 함수로 연관시킬 수 있는 경우도 있다. 관심 있는 물성을 제일원리(first-principles) 전자구조 계산을 통하여 성능지수(figure of merit)로 계산 할 수 있다면 물성을 먼저 정의하고 해당 초기능성 결정구조를 찾는 문제 풀이는 가능해진다. 그림 1 에 표시된 것처럼 이러한 접근법은 결정구조에서 출발하여 전자구조 계산 결과를 얻어내 는 방식과는 차별화된다. ${ }^{[1]}$ 아울러, 얻어진 소재의 구조적, 열적 안정성은 별도의 조사가 필요할 것이다.

현재 사용되고 있는 제일원리 전자구조 계산의 정밀도에 대 한 논의가 필요하다. 총에너지 그리고 전자구조 계산의 정밀도 는 소재 설계/탐색 기술의 필요조건이기 때문이다. 제일원리 전 자구조 계산을 활용한 응집물질 연구 분야는 지난 40 년 동안 비약적으로 발전해왔다. 해당 기간 지속적으로 성능이 향상된 계산자원의 보급 또한 무시할 수 없다. 전통적으로 응집물질 전

\section{REFERENCES}

[1] A. Franceschetti and A. Zunger, Nature (London) 402, 60 (1999). 
Chromosome $=a, b, c, \alpha, \beta, \gamma,\left\{\boldsymbol{A}_{/}\right\}$
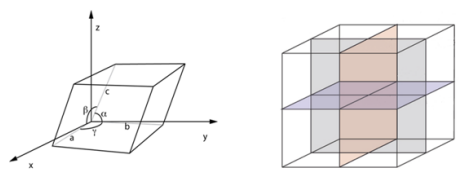

(a)

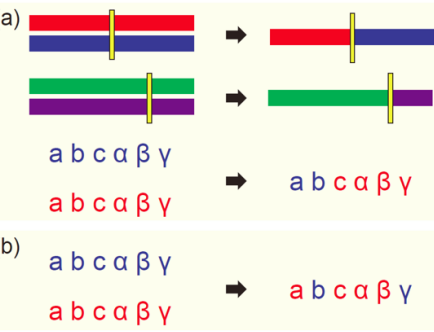

Fig. 2. (a) An illustration of the single-point crossover operation. Vertical lines represent crossover points and long horizontal bars stand for one-dimensional representation of atoms in molecules or solid systems. (b) An example of the uniform crossover operation for the lattice parameters, $a, b, c, \alpha, \beta, \gamma$.

자구조 계산 연구는 밀도함수론(density functional theory)에 바탕을 둔 방법이 널리 사용되어왔다. ${ }^{[2]}$ 다행히도 지난 수십 년 간의 연구와 검정으로 몇 가지 잘 알려진 문제점들을 잘 이해 하면 충분히 초기능성 소재를 설계/탐색할 수 있다. 아울러, 최 근 널리 보급된 계산자원도 충분히 초기능성 소재를 설계/탐색 할 수 있는 수준에 도달하였다. ${ }^{[3]}$

대용량 계산자원을 활용하는 방식으로 제일원리 전자구조 계 산에 바탕을 둔 소재 설계/탐색 연구 분야는 그렇게 긴 역사를 가지고 있지는 않다. 이러한 사실은 제일원리 전자구조 계산의 복잡성에 기인한다. 새롭게 설계/탐색된 결정구조의 안정성 검 증은 필수적이다. 이론적인 관점에서 결정구조의 안정성이라는 것은 구조적으로 그리고 열적으로 얼마나 안정한지를 제일원리 계산으로 검정하는 것이다. 구조적으로 안정하다는 것은 격자진 동 방식으로는 다른 구조로 스스로 변환되지 않는다는 것을 의 미한다. 즉, 준안정(metastable) 상태를 의미한다. 또한, 외부 온도가 올라가면서 결정구조가 다른 구조로 바뀌는지도 동시에 조사해야한다. 어느 온도까지 해당 결정구조가 안정한 상태를 유지하는지 랑쥐방(Langevin) 방정식을 풀어서 조사해야한다. 즉, 유한 온도, 유한 압력에서 최소 에너지 장벽의 크기를 조사 해야한다. 제일원리 격자 진동모드 계산과 제일원리 분자동역학 계산으로 결정구조의 구조적, 열적 안정성을 검정할 수 있다.

결정구조는 그림 2에서 제시한 것처럼 단위셀(unit cell)의 모 양을 나타내는 6 개의 매개변수 $(a, b, c, \alpha, \beta, \gamma)$ 와 단위셀 내부에 원자들의 구체적인 배열로 나타낼 수 있다. 예를 들어, 탄소로 구성된 다이아몬드 구조의 경우, 단위셀에 2 개의 탄소 원자들이 대각선 방향으로 배치하고 단위셀은 면심입방체(facecentered cubic) 구조로 이루어져있다. 이 경우 $2 \times 3+6=12$
개의 자유도가 총에너지 함수를 최적화시킨 것으로 볼 수 있 다. 수학적으로는 12 개의 변수를 바꾸어서 안정한 다이아몬드 결정구조를 얻어낼 수 있다.

2014년 물리학과 첨단기술 12월 제23권 12호에 발표된 '전 자구조계산 신물질 디자인 연구실'이라는 글에서 초기능성 소재 의 설계/탐색에 대한 초기의 접근방법을 간략하게 소개한 바 있다.

\section{광역 최적화 방법과 제일원리 전자구조 계산의 결합}

광역 최적화(global optimization) 방법은 응용수학 그리고 수 치 해석학 분야에서 개발된 알고리듬으로서 특정 조건을 따르 는 목적함수(objective function)의 광역적인 최적화를 제공한 다. 광역 최적화 방법과 제일원리 전자구조 계산을 결합하면 소 재 설계/탐색에 응용할 수 있다. 예를 들어, 목적함수를 엔탈피 (enthalpy)로 선택하면 주어진 외부 압력에서 가장 낮은 엔탈피 를 가지는 결정구조를 제일원리 전자구조 계산을 통하여 찾을 수 있다. 가장 주목해야할 점은 원자수가 증가할수록 가능한 에 너지(또는 엔탈피)함수 국소 최소점의 수는 지수적으로 증가한 다는 사실이다. ${ }^{[4]}$ 강력한 광역 최적화 방법이 필요한 이유가 여 기에 있다.

유전 알고리듬(genetic algorithm), ${ }^{[5]}$ 입자군 최적화(particle swarm optimization) 알고리듬[6] 등이 광역 최적화 방법으로 이 공계에서 널리 이용되고 있다. 두 가지 방법에서는 모두 여러 개 의 잠정적인 해들(개체들)을 동시에 고려한다. 유전 알고리듬은 생명정보의 유전현상을 시늉하는 광역 최적화 방법으로서 잠정 적인 두 개 해들 사이의 교차(crossover)와 잠정적인 하나의 해 에 대한 변이(mutation)를 동시에 활용하여 보다 나은 해를 찾 는다. 부모세대의 교차/변이를 통하여 자식세대의 해들을 얻어 내는 것이다. 유전 알고리듬에서 교차와 변이가 필수적인 요소이 다. 부가적 요소로서 유전 알고리듬에는 선택(selection)과 대체 (replacement)가 있다. 선택은 목적함수 값이 작은 개체들에게 교차 또는 변이될 확률을 더 높게 부가하는 것을 지칭한다. 대체 는 현재까지 얻어진 다수의 해들 중 하나는 폐기하고 새로운 해

\section{REFERENCES}

[2] P. Hohenberg and W. Kohn, Phys. Rev. B 136, B864 (1964).

[3] A. R. Oganov (Ed.), Modern Methods of Crystal Structure Prediction (Wiley-VCH Verlag GmbH \& Co. KGaA, Weinheim, 2010).

[4] F. H. Stillinger, Phys. Rev. E 59, 48 (1999).

[5] J. H. Holland, Adaptation in Natural and Artificial Systems (MIT press, Cambridge, MA, 1992).

[6] J. Kennedy and R. C. Eberhart, Swarm Intelligence (Morgan Kaufmann, 2001). 
를 취하는 것을 말한다. 물론, 더 작은 목적함수 값을 가지는 개 체가 나타난 경우에 한해서 대체가 이루어진다.

입자군 최적화 방법은 개체들의 사회활동을 시늉하는 방식으 로 계산이 진행된다. 무리의 속 개체(입자, 해)들 사이의 정보교 환(사회활동 시늉)을 이룩하고 목적함수 값 기준으로 잠정적인 개체(해)들의 개선을 얻어낸다. 개체 하나의 최적화 상태 갱신과 개체 무리 전체의 최적화 상태 갱신을 공유함으로써 여러 개체 들의 점진적인 개선을 얻어낸다. 유전 알고리듬에 비해서 입자군 최적화 알고리듬이 보다 더 간단하다. 그 밖에도 다양한 광역 최 적화 방법들이 개발되어 사용되고 있다. 하지만 그 어떤 광역 최 적화 알고리듬도 완벽하지는 않다. 결정론적으로 광역 최적화된 해를 제공하는 알고리듬은 존재하지 않는다. 컴퓨터 프로그램으 로 풀기 어려운 최적화 문제들은 너무나도 많다.

그 동안 개발된 제일원리 계산에 바탕을 둔 소재 설개/탐색 프로그램들로는 USPEX, ${ }^{[7]}$ CALYPSO, ${ }^{[8]} \mathrm{XtalOpt}^{[9]}$ 등이 있다. 본 해설에서는 최근에 저자들이 개발한 초기능성 소재 설계/탐 색 프로토콜(Ab initio MAterials DEsign Using conformational Space annealing, AMADEUS) ${ }^{[10]}$ 에 대해서 기술하고자 한다. 여러 프로토콜들이 사용자 입장에서는 유사해 보이지만 실제로 사용된 알고리듬의 세부항목들은 서로 다르다. AMADEUS는 Conformational Space Annealing(CSA) 알고리듬 ${ }^{[1,12]}$ 과 제일 원리 전자구조 계산을 결합한 것이다. CSA 알고리듬은 유전 알고리듬, 국소 최적화(local optimization), 그리고 풀림시늉 (simulated annealing) 세 가지 계산 방법을 결합한 광역 최적 화 방법으로서 매우 복잡한 수학, 공학, 생물학, 물리학 문제들 을 푸는데 적용되어서 해당 최적화 성능이 우수한 것으로 잘 알 려져 있다.

CSA 알고리듬은 국소 최적화된 해만 취급하며 기본적으로 다 수의 다양한 특징을 가지는 잠정적인 해들을 생산한다. 목적함수 값 기준으로 잠정적인 해들을 오름차순으로 정렬하여 보관한다. 이렇게 만들어진 해들 사이의 차이를 표시하는 '거리'를 정의한 다. 잠정적으로 만들어진 해들 사이의 '거리'를 모두 계산하고 평균하여 그 절반을 최초의 '차단거리'로 둔다. 이 '차단거리'는 계산이 진행될 때 아주 조금씩 작아지게 만들어 둔다. 새로운 해 를 찾기 위해서, 교차와 변이를 확률적으로 선택하여 사용하고 연이어 국소 최적화 작업을 진행한다. 이렇게 해서 얻어진 새로 운 해를 이용하여 기존에 얻어둔 해들과 차이점을 계산한다. 즉, '거리'를 모두 다 계산한다. '거리'가 가장 작은 유사한 해를 하 나 찾을 수 있다. 이때, 이들 사이의 '거리'가 현재의 '차단거리' 보다 같거나 작으면 두 해들은 서로 유사한 해로 간주한다. 두 가지 중에 하나를 선택하고 나머지 하나는 더 이상 고려하지 않 는다. 물론, 목적함수 값이 더 작은 해를 선택한다. 반대로 '거리' 가 '차단거리'보다 더 클 경우에는 새롭게 얻어낸 해를 새로운

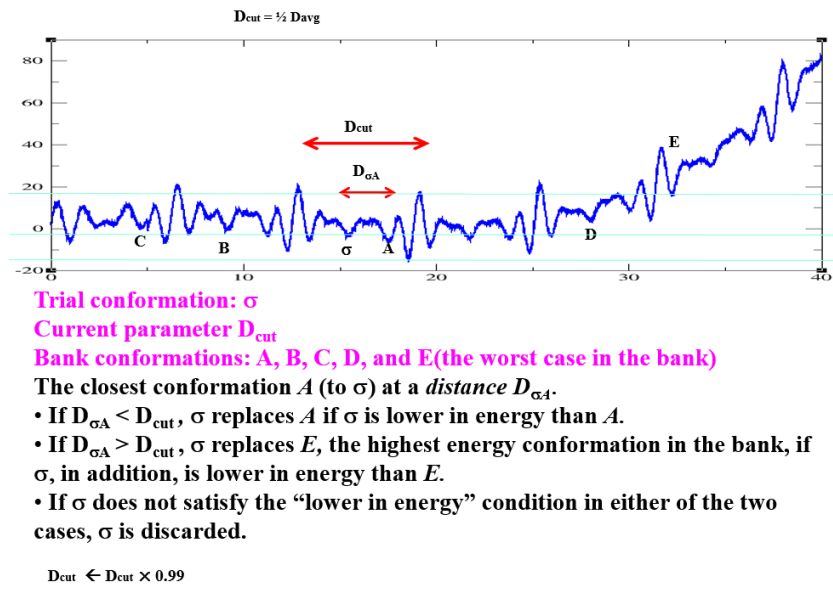

Fig. 3. Maintaining diversity is a necessary but not a sufficient condition for the good performance of CSA. In order to cover the whole low-lying basin areas in the landscape of the objective function, new types of solutions must be continuously supplied by the mutation/crossover procedures as much as possible.

형식의 해라고 해석한다. 이때, 새로운 형식의 해가 가지는 목적 함수 값은 기존에 얻어둔 해들 중에서 가장 큰 목적함수 값과 직 접 비교한다. 새로운 형식의 해가 가지는 목적함수 값이 더 작은 값이면 새로운 형식의 해가 편입된다. 기존의 해는 파기되고 더 이상 고려되지 않는다. 즉, CSA 알고리듬에서는 그림 3에서 표 시된 두 가지 서로 다른 형식의 대체가 있다. 하나는 유사한 형 식의 해를 대체하는 방법이고 다른 하나는 새로운 형식의 해를 대체하는 방법이다. 이러한 두 가지 방식의 대체는 유전 알고리 듬과 $\mathrm{CSA}$ 알고리듬이 특징적으로 구별되게 하는 것들 중 하나 이다. 일반적으로 이러한 대체는 보다 더 다양한 형식의 해들을 동시에 확보할 수 있게 한다.

$\mathrm{CSA}$ 알고리듬과 제일원리 전자구조 계산 방법을 효율적으로 결합하는 것이 가능하다. ${ }^{[13-15]}$ 제일원리 전자구조 계산에서는 국 소 최소화가 잘 정의된다. 즉, 단위셀 내부의 모든 원자들이 힘

\section{REFERENCES}

[7] C. W. Glass, A. R. Oganov and N. Hansen, Comput. Phys. Commun. 175, 713 (2006).

[8] Y. Wang, J. Lv, L. Zhu and Y. Ma, Comput. Phys. Commun. 183, 2063 (2012).

[9] D. C. Lonie and E. Zurek, Comput. Phys. Commun. 182, 372 (2011).

[10] I.-H. Lee, Y. J. Oh, S. Kim, J. Lee and K. J. Chang, Comput. Phys. Commun. 203, 110 (2016).

[11] J. Lee, H. A. Scheraga and S. Rackovsky, J. Comput. Chem. 18, 1222 (1997).

[12] J. Lee, I.-H. Lee and J. Lee, Phys. Rev. Lett. 91, 080201 (2003).

[13] J. Ihm, A. Zunger and M. L. Cohen, J. Phys. C 12, 4409 (1979).

[14] O. H. Nielsen and R. M. Martin, Phys. Rev. Lett. 50, 697 (1983).

[15] G. Kresse and J. Furthmüller, Comput. Mater. Sci. 6, 15 (1996). 
을 받지 않고, 6 개의 매개변수 $(a, b, c, \alpha, \beta, \gamma)$ 의 변화에 대 한 엔탈피의 변동이 없는 상태를 국소 엔탈피 최소화를 통해서 만들어 낼 수 있다. 이렇게 얻어낸 결정구조로부터 시작하여 그 결정구조의 전자구조 계산을 수행할 수 있다. 원하는 전자구조의 성향을 목적함수 형식으로 정의하고, 목적함수를 광역 최적화하 면 초기능성의 결정구조를 얻어낼 수 있다.

$\mathrm{CSA}$ 알고리듬에서는 유전 알고리듬에서처럼 교차와 변이를 활용하여 새로운 결정구조를 만들어 내려고 시도한다. 결정구조 를 표현하는 방식은 교차작업과 변이작업이 쉽게 정의되는 것으 로 정한다. 교차는 두 개의 서로 다른 결정구조들로부터 제 3 의 새로운 결정구조를 만들어 내는 것이다. 물론, 국소 엔탈피 최소 화 과정이 추가적으로 필요하다. 교차의 의미는 현재까지 얻어진 결정구조들의 특징을 가능한 한 잘 '이용하자는 것이다. 반면, 변이의 의미는 보다 더 새로운 구조를 찾는다는 것이다. 즉, '탐 험'을 의미한다. 이와 같이 '이용과 '탐험' 사이의 균형이 유전 알고리듬에서 반드시 필요하다.

6 개의 매개변수 $(a, b, c, \alpha \beta, \gamma)$ 와 단위셀 내부에 원자들의 배열로 결정구조를 표현할 수 있다. 따라서 서로 다른 두 개의 결 정구조들로부터 그림 2 에 표시된 것처럼 1 차원 표현방식으로 배 열된 새로운 6 개의 매개변수를 다양한 방법으로 만들어낼 수 있 다. 또한, 일반적인 3 차원 회전 작업을 통해서 단위셀을 임의의 방향으로 회전시켜 놓을 수 있다. 이렇게 할 경우 항상, 단위셀의 좌측('어머니')과 우측('아버지')을 구분할 수 있어서 '어머니'와 '아버지'의 유전정보를 보다 쉽게 선택할 수 있다. 이때 $x$ 축 방 향을 기준으로 좌측과 우측을 구분하는 것은 매우 일반적인 구분 기준이 된다. $x$ 축 방향으로 원자들의 위치를 오름차순으로 정렬 할 수 있다. 이것은 1 차원 표현방식으로 볼 수 있다. 이러한 1차 원 표현방식을 이용하면 교차작업을 쉽게 수행할 수 있다. 반드 시 ‘ $1 / 2+1 / 2$ ' 방식으로 교차작업을 수행해야만 하는 것은 아니 다. ' $1 / 4+3 / 4$ ' 방식도 가능하다. 다양한 교차작업과 다양한 변이 작업을 모두 사용한다. 확률적으로 선택하여 다양한 교차작업을 도입한다. 변이작업에도 매우 다양한 방식이 있다. 근접거리 변 이, 장거리 변이, 물결 모양의 변이, 뒤틀림 변이, 결함 제거 변 이, 무른 격자진동 모드 변위, 국부 변이 등 매우 다양한 변이가 가능하다. 마찬가지로 확률적으로 선택하는 방식을 도입하면 매 우 다양한 변이들을 모두 다 이용할 수 있다. 원자-원자 거리가 과도하게 작아지는 것을 원초적으로 피하게 만들어 줄 필요가 있 다. 이것은 몬테칼로(Monte Carlo) 방식으로 구현할 수 있다.

$\mathrm{CSA}$ 계산을 시작할 때, 다양한 공간군들을 이용하여 무작위 로 임의의 대칭적 구조들을 만들어 낸다. 3차원에서는 14 가지 브라베 격자, 2 차원에서는 5 가지 브라베 격자가 가능하다. 특별 히 3 차원 결정 구조의 경우 32 개의 결정학 점군과 14 가지 브라 베 격자의 조합으로 230 가지 공간군이 만들어진다. 대응되는 개

\section{Conformational Space Annealing (CSA)}

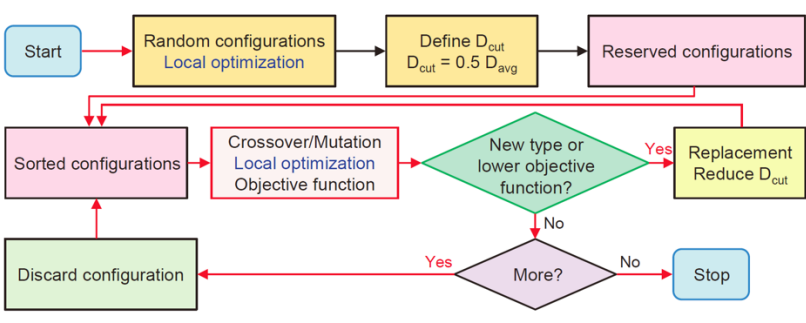

No human intervention

Parallel-in-parallel

Massively parallel (Extensible)

Fig. 4. A flowchart of the CSA method for the inverse method of materials design and discovery.

념으로 17 가지 평면 대칭군이 있다. 임의의 대칭성을 가지고 있 는 결정구조들은 즉시 엔탈피 최소화 과정을 통과하게 된다. 이 렇게 만들어진 결정구조에 대한 목적함수 값 계산을 수행하게 된다. 추가적으로 목적함수 값 기준으로 시도 해들을 오름차순으 로 정렬하여 보관한다. 이렇게 만들어진 최초의 결정구조 모임을 first bank라고 한다. 이러한 first bank로부터 초기의 '차단거리' 가 정의될 수 있다. 통상, 평균 '거리'의 절반 값을 최초의 '차단 거리’로 선택한다. 이렇게 '차단거리’ 초기화가 완료되면 본격적 으로 CSA 계산이 진행된다. 다양한 교차 또는 변이로부터 새로 운 시도 해가 만들어지고 국소 엔탈피 최소화 과정을 통과하여 최종적으로 목적함수 값 계산까지 진행한다. 이러한 상태에서 앞 서 언급한 두 가지 형태의 대체 중에서 특정 대체 하나가 가능한 지를 따져본다. 대체가 이루어졌다면 시도 해들을 다시 목적함수 값 기준 오름차순으로 정렬하여 bank에 보관한다. 이때 bank는 계속해서 갱신될 것이다. first bank는 갱신되지 않는다. 이러한 방식으로 계속해서 그리고 병렬적으로 CSA 계산을 수행한다. 물론, '차단거리'는 계산이 진행되면서 천천히 조금 더 작은 값 으로 바뀌게 된다.

일반적으로 제일원리 전자구조 계산은 초고속 통신망을 활용 한 병렬계산 방식으로 계산이 수행된다. CSA 계산에서는 이러 한 다수의 초고속 병렬계산들이 다수의 폴더들에서 독립적으로 진행되게 된다. 즉, CSA 계산은 병렬 속의 병렬(parallel-in-parallel) 계산 방식으로 수행되기 때문에 초고도 병렬계산으로 분류 된다. 통상 국소 엔탈피 최소화 과정이 가장 많은 계산자원을 필 요로 한다. 아울러, 이러한 독립적인 계산 작업들은 작업마다 소 요되는 시간이 서로 다르다. 하나의 목적함수 값 계산이 완료되 면 또 다른 새로운 목적함수 값 계산이 즉시 시도될 수 있게 한 다. 이렇게 함으로써 초고도 병렬 효율성을 확보할 수 있다. 그 림 4에서 표시된 CSA 계산은 계산자원의 증가에 곧바로 대응할 수 있는 확장성을 가지고 있다. 


\section{초기능성 소재 설계/탐색: 태양전지 소재}

실리콘은 지각에서 두 번째로 많이 분포하는 원소이다. 또한 전자소자 소재로서 널리 이용되고 있다. 실리콘과 관련된 소재 공정 기술은 오랜 기간 지속적으로 연구되어왔다. 무엇보다도 실리콘은 저가 친환경 소재로 알려져 있다. 다이아몬드 구조를 가지는 실리콘 결정구조는 전자소자 소재로 널리 이용되지만 광흡수 또는 광방출 소재로서는 부적격이다. 왜냐하면 해당 전 자구조가 간접-밴드갭(indirect bandgap)을 가지고 있기 때문 이다. 기존의 전자소자와 광소자의 결합이라는 측면에서 광소 자 소재가 실리콘 기반이면 이상적이다. 이는 두 가지 소자들 의 접합에서 발생하는 격자상수 불일치 문제를 최소화할 수 있기 때문이다. 따라서 실리콘으로 만들어졌지만 전자구조가 직접-밴드갭(direct bandgap)을 가지는 새로운 실리콘 결정구 조가 개발된다면 매우 유용한 초기능성 소재가 될 수 있을 것 이다.

직접-밴드갭을 가지는 실리콘 결정구조의 개발은 태양전지 (solar cell) 소재 개발에서도 매우 중요하다. 사실 태양전지 소 재로서 실리콘은 최적의 밴드갭 크기 $(1.12 \mathrm{eV})$ 를 가지고 있다. 하지만 간접-밴드갭이라는 한계로 인하여 성능지수 관점에서 최고의 태양전지 소재는 될 수 없다. 최고 성능지수를 가지려 면 태양전지 소재가 반드시 직접-밴드갭 전자구조를 가지고 있 어야 한다. 태양전지 연구 분야에서는 태양전지 효율에 대한 아주 일반적인 이론 모델이 있다. 반도체의 전자구조가 직접밴드갭을 가지고 있으며 그 크기가 $1.1 \sim 1.3 \mathrm{eV}$ 일 때 최고의 태양전지 효율(성능지수)을 얻을 수 있다. 밴드갭 크기 에너지 에서 이상적인 전이가 가능할 때를 가정한 이론 모델은 최고의 태 양전지 효율로 33.7\%를 예측한다. 이것을 Shockley-Queisser 극한 ${ }^{[1]}$ 이라고 한다. 이 이론 모델은 실험 사실과 아주 잘 일 치한다. 이 모델은 유한 온도에서 만들어진 전자-정공 중 일부 가 재결합을 할 확률을 모두 고려한 것이다. 최고의 태양전지 소재가 되기 위해서는 소재의 전자구조가 직접-밴드갭을 가져 야 한다. 보다 더 엄밀하게 말하면 태양광이 태양전지 소재에 흡수될 때 따져야 할 조건이 하나 더 있다. 직접-밴드갭 크기 에 해당하는 밴드 가장자리들 사이에서 일어나는 전이가 허용 되어 있어야 한다. 즉, 밴드 가장자리들 사이의 쌍극자-전이가 허용(dipole-allowed)되어 있어야 최고의 광흡수 소재가 된다. 쌍극자 전이가 허용된 직접-밴드갭을 형성하는 전자구조를 확 보한 소재가 최고 성능지수의 광흡수 또는 광방출 소재가 될 수 있는 것이다.

직접-밴드갭을 가지는 실리콘 결정구조를 찾는 문제 풀이는 목적함수 설계와 광역 최적화 계산 수행으로 진행되어 왔었다. 하지만, 준-직접-밴드갭(quasi direct-bandgap)을 가지는 결정
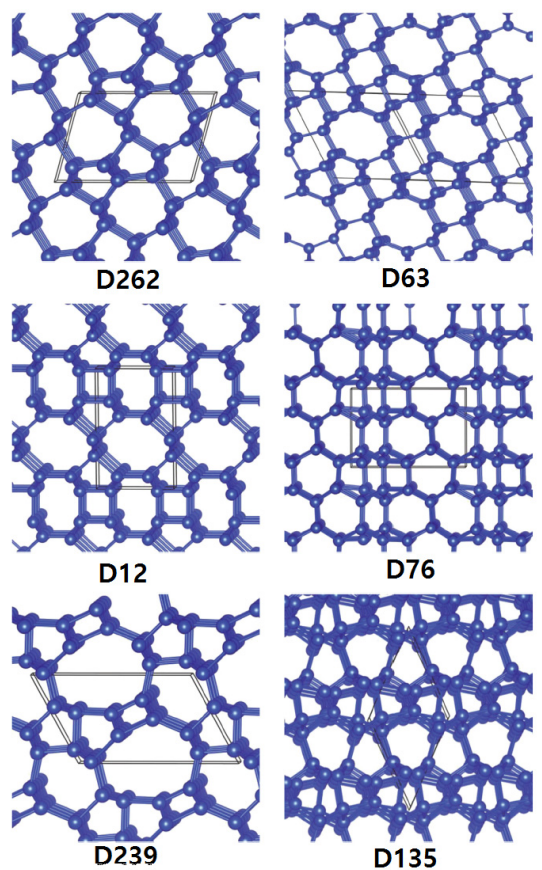

Fig. 5. Atomic structures of D262, D63, D12, D76, D239, and D135. Coordination defects do not exist. Black solid lines represent the primitive cells.

구조들을 찾아내는 수준에 머물러 있었다. 하지만, 앞서 설명 한 CSA 방법을 동원하여 그림 5에 표시된 직접-밴드갭을 가 지는 실리콘 결정구조들을 최초로 설계/발견하는 연구를 수행 한 것은 최근의 일이다. ${ }^{[17]}$ 얻어진 결정구조가 단위셀 결정구조 인가를 먼저 확인해야 하고 그 다음 전자구조 계산을 통하여 직접-밴드갭이 형성되었는지를 추가로 확인해야 한다. 또한, 외 부 압력이 주어졌을 때, 밴드갭의 크기가 압력에 따라서 어떻 게 바뀌는지도 관찰의 대상이다. 목적함수는 간접-밴드갭 크기 를 최대화하며 동시에 직접-밴드갭 크기를 최소화하는 방식으 로 잡았다. 추가적으로 계산된 밴드갭 크기가 $1.1 \sim 1.3 \mathrm{eV}$ 영 역에 들어오지 못할 경우 벌점을 목적함수에 추가하였다. 최종 적인 소재의 태양전지 성능지수를 제일원리 전자구조 계산을 통하여 얻어냈다. 태양전지 성능지수에 대한 이론 모델로서 앞 서 언급한 것보다 더 일반적인 이론 모델 구성이 가능하다. 제일원리 전자구조 계산으로부터 얻어낼 수 있는 흡수 스펙트 럼을 직접 이용하는 계산방식이 SLME(spectroscopic limited maximum efficiency $)^{[18]}$ 모델이다. 밴드갭 크기뿐만 아니라 전 자의 전이확률을 구체적으로 취급하는 방식이다. 아울러, 전자-

\section{REFERENCES}

[16] W. Shockley and H. J. Queisser, J. Appl. Phys. 32, 510 (1961).

[17] I.-H. Lee, J. Lee, Y. J. Oh, S. Kim and K. J. Chang, Phys. Rev. B 90, 115209 (2014).

[18] L. Yu and A. Zunger, Phys. Rev. Lett. 108, 068701 (2012). 


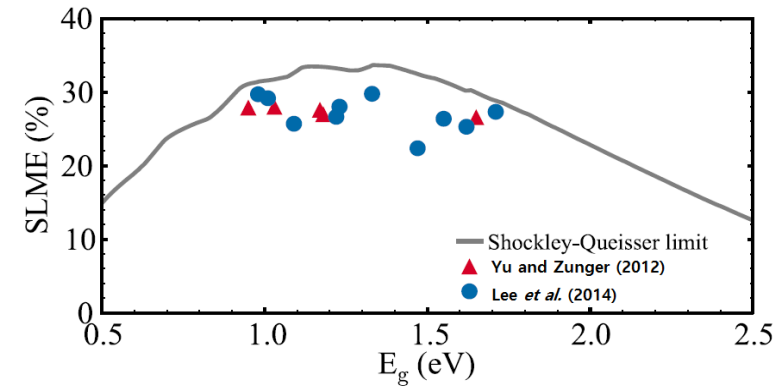

Fig. 6. The photovoltaic efficiencies of designed silicon crystals and top five systems (CulnTe, CulnSe $_{2}$, AglnTe, AglnSe 2 , and CuGaSe ${ }_{2}$ ) proposed by $\mathrm{Yu}$ and Zunger.

정공 상호작용까지 명시적으로 취급한다. SLME 모델은 소재 박막 두께까지 고려할 수 있다. 이러한 이론 모델로부터 열린 회로 전압, 최대출력 전압, 태양전지 효율을 박막 두께의 함수 로 계산할 수 있다.

얻어진 결정구조의 구조적, 열적 안정성 조사도 동시에 수행 하였다. 격자진동 모드에서는 허수 진동수가 없었다. 결정구조 에 따라서 500 900 K 온도에서 안정된 결정구조를 유지하였 다. 그림 6에서처럼 새로운 실리콘 결정구조에 대한 정밀 전자 구조 계산을 통하여 태양전지 성능지수(SLME)를 제일원리 전 자구조 계산으로부터 얻었다. 일반적인 밀도함수론으로 계산한 밴드갭 크기보다 더 정확하게 밴드갭 크기를 계산하는 $G W$ 방 법 ${ }^{[19,20]}$ 을 활용하였으며 추가적으로 전자-정공 상호작용까지 고 려하는 Bethe-Salpeter 방정식 ${ }^{[21]}$ 풀이를 하여 광흡수 스펙트 럼을 계산하였다. 이렇게 계산된 광흡수 스펙트럼을 기반으로 새로운 실리콘 결정구조 박막 두께에 따른 태양전지 성능지수 (SLME)를 계산하였다. $0.5 \mu \mathrm{m}$ 두께의 새로운 결정구조 실리 콘 박막을 이용할 경우 태양전지 효율이 약 $30 \%$ 에 근접할 수 있음을 보였다.

아울러 초격자 상태의 실리콘 결정구조는 그림 7 에서 표 시한 것처럼 특별히 안정한 상태로서 여러 가지 초격자구조 $\left[\mathrm{Si}(111)_{n} / \mathrm{Si}(\mathrm{SC}), n=3,4,5\right]$ 들이 직접-밴드갭을 가지게 된다 는 사실을 알아내었다. ${ }^{[22]}$ 총에너지 관점에서 매우 안정한 구 조이다. [111] 방향의 실리콘 구조에 Seiwatz 체인이 결함으로 포함된 결정구조이다. 두 개의 오각형 결합 고리와 한 개의 팔 각형 결합 고리를 가지고 있어서 빈공간의 크기가 돋보이는 결정구조이다. 실리콘 다이아몬드 구조에 비해서 불과 26 42 $\mathrm{meV} / \mathrm{atom}$ 정도 에너지가 높은 준안정 상태이다. 격자진동 모 드 계산으로 초격자구조들이 구조적으로 안정한 상태임을 알았 다. 또한, 제일원리 분자 동역학 계산으로 $1100 \mathrm{~K}$ 온도에서도 열적으로 안정한 구조라는 것을 확인하였다. 직접-밴드갭--간접 -밴드갭 전자구조 전환이 초격자구조를 정의하는 하나의 숫자 $(n)$ 에 따라서 이루어짐을 조사하였다. 설계/탐색된 실리콘 기
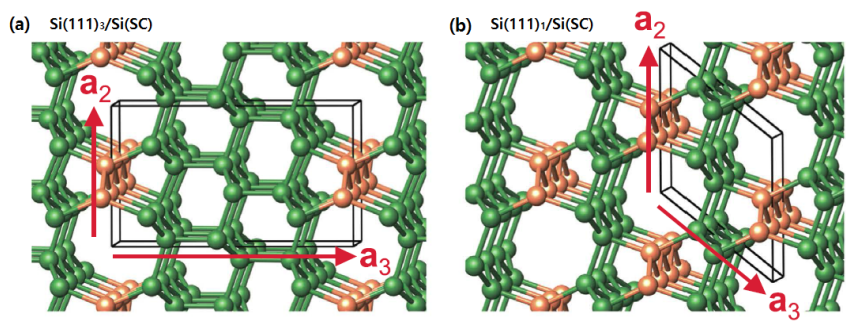

Fig. 7. The $\mathrm{Si}(111)_{n} / \mathrm{Si}(\mathrm{SC})$ superlattices composed of $\mathrm{Si}(111)$ layers (green) and a defective layer of Seiwatz chains (orange) are shown for (a) $n=3$ and (b) $n=1$. The black parallelepiped represents the unit cell spanned by the lattice vectors, $\mathbf{a}_{1}, \mathbf{a}_{2}$, and $\mathbf{a}_{3}$.

반 초격자구조들은 직접-밴드갭을 가지면서 쌍극자-전이가 허 용되어 있어서 최고의 태양전지 효율을 낼 수 있음을 확인하 였다. 이들은 최고의 태양전지 효율을 나타내는 소재들과 동급 의 성능지수를 나타내었다. 태양광 전지 최고 효율을 낼 수 있는 소재들로는 $\mathrm{CuInTe}_{2}, \mathrm{CuInSe}_{2}, \mathrm{AgInTe}_{2}, \mathrm{AgInSe}_{2}, \mathrm{AgInTe}_{2}$, $\mathrm{CuGaSe}_{2}$ 등이 잘 알려져 있다. 다이아몬드 결정구조를 가진 실리콘 소재를 사용할 경우 약 $200 \mu \mathrm{m}$ 두께의 실리콘 박막에 서 약 $20 \%$ 의 태양전지 효율을 기대할 수 있다. 하지만 최고의 효율을 내는 소재들에서는 $0.5 ~ 1.0 \mu \mathrm{m}$ 두께의 박막으로 약 $30 \%$ 태양전지 효율을 얻을 수 있다. 이들 소재는 매우 고가 소재이다. 물론, 특수 목적에 제한적으로는 활용되어질 수 있 는 소재들이다.

실리콘 초격자구조 $\left[\mathrm{Si}(111)_{n} / \mathrm{Si}(\mathrm{SC}), n=3,4,5\right]$ 는 매우 안 정한 다이아몬드 구조를 기본구조 항목으로 형성된 구조이다. 따라서 총에너지 관점에서 매우 유리한 결정구조가 된다. 또 한, 최근 합성실험 연구에서 실리콘 초격자구조와 매우 유사한 구조가 합성이 되었다. ${ }^{[23]}$ 이 구조는 준직접-밴드갭 구조를 가 지고 있으면서 총에너지 관점에서도 매우 유리한 것이다. 구 조들의 유사성으로 판단할 때 이론적으로 설계/탐색된 초격자 구조들이 실제 실험에서 합성될 가능성이 없다고 볼 수 없는 수준이다. 실험적으로 측정된 밴드갭 크기와 이론적으로 계산 된 밴드갭 크기는 서로 잘 일치한다. 아울러 직접-밴드갭은 아 니지만 준직접-밴드갭 전자구조로도 매우 높은 태양광 흡수가 가능하다는 사실이 실험적으로 측정되어 주목받았다. 적어도 실리콘 물질에 대한 제일원리 전자구조 계산이 얼마나 정확한

\section{REFERENCES}

[19] M. S. Hybertsen and S. G. Louie, Phys. Rev. B 34, 5390 (1986).

[20] L. Hedin, J. Phys. Condens. Matter 11, R489 (1999)

[21] E. E. Salpeter and H. A. Bethe, Phys. Rev. 84, 1232 (1951),

[22] Y. J. Oh, I.-H. Lee, S. Kim, J. Lee and K. J. Chang, Sci. Rep. 5, 18086 (2015).

[23] D. Y. Kim, S. Stefanoski, O. O. Kurakevych and T. A. Strobel, Nature Mater. 14, 169 (2014). 


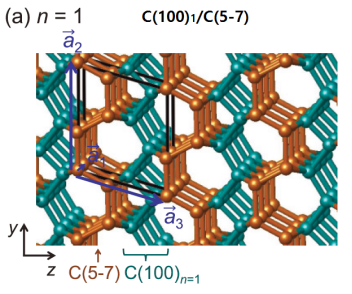

(c) $n=2$ (type II) $\quad \mathrm{C}(100)_{2} / \mathrm{C}(5-7)$

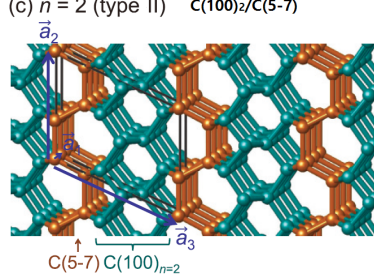

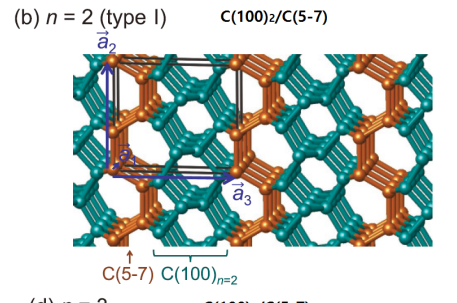

$\mathrm{C}(100)_{3 / C} \mathrm{C}(5-7)$

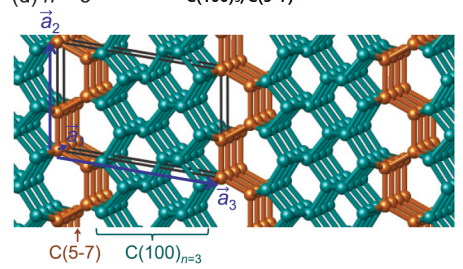

Fig. 8. The atomic structures of the $C(100)_{n} / C\left(5^{-7}\right)$ superlattices for (a) $n=1$, (b) $n=2$ (type I), (c) $n=2$ (type II), and (d) $n=3$. Colored cyan and brown circles denote the $C$ atoms which belong to the $C(100)$ and $C(5-7)$ layers, respectively. The black parallelepiped represents the unit cell spanned by the lattice vectors $\mathbf{a}_{1}, \mathbf{a}_{2}$, and $\mathbf{a}_{3}$.

지를 보여주는 계산과 실험 결과라고 판단된다.

\section{초기능성 소재 설계/탐색: 발광다이오드 소재}

잘 알려진 것처럼 탄소는 지각에 풍부하게 분포하는 원소이 며 매우 다양한 동소체를 가지는 원소이다. $\mathrm{C}_{60}$, 탄소 나노튜 브, 그래핀, 흑연, 다이아몬드 등 매우 다양한 탄소 기반 원자 구조들이 잘 알려져 있다. 다이아몬드 소재는 넓은 밴드갭(5.5 $\mathrm{eV})$ 을 가지고 있어서 고전압 작동 전자소자 소재로서 매력적이 다. 또한 매우 높은 포화 전자표류속도, 전기전도도를 가지고 있다. 실리콘 다이아몬드 결정구조와 마찬가지로 다이아몬드도 간접-밴드갭 특성의 전자구조를 가지고 있다.

직접-밴드갭을 가지는 탄소 결정구조는 없을까? 앞서 설명한 소재 설계/탐색 프로토콜을 그대로 사용하여 초격자구조를 가 지면서 직접-밴드갭을 가지는 다수의 탄소 동소체 $\left[\mathrm{C}(100)_{n} /\right.$ $\mathrm{C}(5-7), n=2 \sim 7]$ 를 찾았다. ${ }^{[24]}$ 앞서 실리콘 초격자구조와 마 찬가지로 그림 8에서 제시된 탄소 초격자구조는 총에너지 관 점에서 매우 유리한 결정구조이다. 5각형-7각형 결합 고리들로 형성된 결함층이 [100] 방향의 다이아몬드 구조에 포함된 결정 구조이다. 다이아몬드 구조에 비해서 불과 $46 \sim 134 \mathrm{meV} /$ atom 정도 에너지가 높은 준안정 상태이다. 격자진동 모드 계 산으로 초격자구조들이 구조적으로 안정한 상태임을 알았다. 또한, 제일원리 분자 동역학 계산으로 $2000 \mathrm{~K}$ 온도에서도 열 적으로 안정한 구조라는 것을 확인하였다. 얻어진 직접-밴드갭 크기는 심자외선(deep UV, $5.6 \sim 5.9 \mathrm{eV}, 210 \sim 221 \mathrm{~nm}$ ) 영 역에 해당한다. 초격자구조를 갖는 탄소 결정구조들은 발광다 이오드(LED) 소재로서 매우 적합한 소재임을 정밀 전자구조

계산을 통하여 밝혔다.

설계/탐색된 탄소 기반 초격자구조의 광학적 성능지수를 계 산하기 위해서 III/V족 직접-밴드갭(3.4 eV)을 가지는 질화갈륨 $(\mathrm{GaN})$ 소재와 직접 비교하였다. $\mathrm{GaN}$ 소재는 소위 비선형광학 의 진동수 배가 처리 없이 $405 \mathrm{~nm}$ 발광다이오드가 가능하도 록 해주는 소재이다. GaN 소재는 블루레이 디스크(Blu-ray Disc)의 핵심 부품으로 응용되고 있다.

페르미-황금규칙(Fermi's golden rule)의 공식에 의하면 광학 적 전이확률은 쌍극자 행렬요소(dipole matrix element)의 제 곱에 비례한다. $G W$ 계산과 Bethe-Salpeter 방정식 풀이를 통 해서 탄소 기반 초격자구조가 제공하는 전자구조로부터 쌍극자 행렬요소를 얻었다. 탄소 기반 초격자구조에 대해서 계산된 쌍 극자 행렬요소의 크기는 $\mathrm{GaN}$ 결정구조가 제공하는 전자구조 의 그것과 거의 동일한 값을 가지고 있었다. 따라서 설계/탐색 된 탄소 기반 초격자구조가 합성된다면 매우 우수한 LED 소 재가 될 것으로 기대된다.

심자외선은 세균의 $\mathrm{DNA}$ 를 파괴하여 살균작용을 할 수 있다. 심자외선 $\mathrm{LED}$ 를 활용하면 오염된 물과 공기를 아주 간단한 방식으로 그리고 저렴하게 정화할 수 있다. 또한, 산업 현장의 경화 장치에 사용될 수 있다. 코팅액, 접착제 경화, 잉크 건조 에 심자외선이 필요하다. 무엇보다 유해 물질을 포함하는 수은 $\mathrm{UV}$ 램프 제품을 대체할 수 있는 소재가 될 수 있다. 일반적으 로 백열등 방식의 조명기기와 비교하여 LED 방식의 조명기기 는 소비전력이 낮고 수명이 긴 특성이 있다.

\section{초기능성 소재 설계/탐색: 위상 물질}

최근 10 년 간 응집물질 연구 분야에서 위상 물질(topological materials)에 대한 연구가 활발히 진행되었다. 그래핀 (graphene) 연구에서 시작된 위상 물질 연구는 3 차원 위상 절 연체(topological insulator) 연구로 이어졌다. 이것은 결정구조 에서도 양자 홀효과를 얻어 낼 수 있다는 것을 의미한다. 여기 서 양자화된 전기전도도는 10 억분의 1 정도로 정밀하게 측정 되는 것이다. 3 차원 결정구조가 한 쪽으로만 움직일 수밖에 없 는 끝머리 상태를 제공한다는 것이다. 현재는 3 차원 디락 준금 속에서 추가적인 대칭성의 붕괴로부터 기인하는 3 차원 바일 (Weyl) 준금속(semimetal) 연구로 급속히 전환되고 있다. 전기 전도도 특성이 특별한 3차원 디락(Dirac)/바일(Weyl) 준금속의 실험적 발견으로 금속도 위상 특성을 가질 수 있다는 사실이

\section{REFERENCES}

[24] Y. J. Oh, S. Kim, I.-H. Lee, J. Lee and K. J. Chang, Phys. Rev. B 93, 085201 (2016). 
밝혀진 것이다. 따라서 위상 물질 연구가 위상 절연체에 국한 될 필요가 전혀 없다. 이것이 새로운 위상 물질의 설계/탐색이 최근 활발하게 진행되고 있는 이유이다.

2017년 현 시점에서 위상 물질은 크게 위상 절연체, 디락 준금속(I, II), 바일 준금속(I, II) 등으로 분류가 가능하다. 시간 역진 대칭(time-reversal symmetry), 반전 대칭(inversion symmetry), 추가적인 대칭(nonsymorphic 또는 symmorphic rotation), 그리고 스핀-궤도 결합(spin-orbit coupling)의 조건과 이들의 다양한 조합방식에 따라서 위상 물질 분류는 더 세분 화될 수도 있다. 반전 대칭성을 가지고 있는 공간군들( 2,10 $\sim 15,47 \sim 74,83 \sim 88,123 \sim 142,147 \sim 148,162 \sim$ $167,175 \sim 176,191 \sim 194,200 \sim 206,221 \sim 230$ )은 이미 잘 알려져 있다.

앞서 개발한 동일한 소재 설계/탐색 방법을 동원하여 특이 한 전기전도도 특성을 보이는 3 차원 탄소 기반 위상 물질을 찾는 연구를 수행했다. 2 차원 소재인 그래핀 결정구조로부터 발원하는 위상 물질 특성을 3 차원 결정구조에서도 그대로 확 인할 수는 없을까? 탄소 기반 결정구조를 목표로 한다면 2차 원 소재 그래핀의 경우와 마찬가지로 스핀-궤도 결합이 없기 때문에 추가적으로 밴드갭을 열려고 하는 효과는 고려하지 않 아도 된다. 탄소는 2 차원 형식의 결합 네트워크 $\left(s p^{2}\right)$ 와 3 차원 형식의 결합 네트워크 $\left(s p^{3}\right)$ 가 모두 다 에너지 관점에서 안정하 여 흑연 결정구조 또는 다이아몬드 결정구조를 각각 만들 수 있다. 한 발 더 나아가 3 차원 형식의 결정구조에 2 차원 그래 핀 결정구조 조각이 부분적으로 편입된 결정구조(interpenetrated graphene network, IGN)를 만들 수도 있다. 그 밖에도 $T_{6}$ 결 정구조, $\mathrm{bco}-\mathrm{C}_{16}$ 결정구조 등이 알려져 있다.

총-에너지가 낮으면서도 $s p^{2}$ 형식과 $s p^{3}$ 형식의 결합 네트 워크가 공존하는 3 차원 결정구조를 보다 체계적으로 찾기 위 해선 광역 최적화 방법을 활용한 계산이 가장 이상적이다. 두 가지 형식이 잘 혼합된 결정구조를 얻기 위해서 순수한 $s p^{2}$ 또는 순수한 $s p^{3}$ 결합 네트워크 구조들에게는 벌점(양의 값을 가짐)을 주는 방식을 취할 수 있다. 최종적으로 목적함수는 총 에너지와 벌점으로 구성되어 있다. 이렇게 할 경우, 얻어지는 구조들은 $s p^{2}$ 그리고 $s p^{3}$ 네트워크 구조들이 잘 혼합된 형식 을 선호하게 되며 에너지 관점에서도 매우 유리한 3차원 결정 구조들을 얻을 수 있다.

제일원리 전자구조 계산과 광역 최적화 계산을 통하여 $s p^{2}$ 그리고 $s p^{3}$ 결합 네트워크 구조들이 잘 혼합된 탄소 기반 결 정구조들을 다수 얻을 수 있었다. 그 중에서 위상 마디선 (nodal line) 특성의 전자구조를 보이는 $C 2 / m$ 공간군을 가지 는 $m-C_{8}$ 결정구조는 여러 가지로 흥미로운 결정구조이다. ${ }^{[25]}$ 그림 9에 표시된 이 결정구조는 $s p^{3}$ 형식 결합(5각형 고리 모

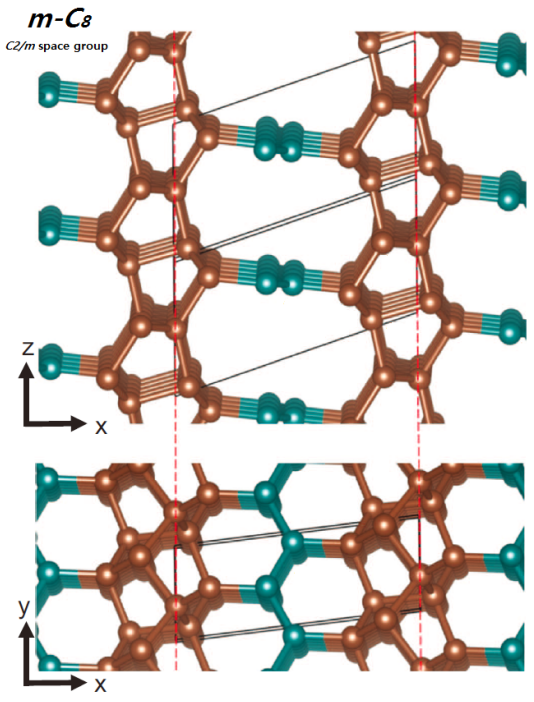

Fig. 9. Side and top views of the atomic structure of $m-c_{8}$ in $c 2 / m$ space group.

양)과 $s p^{2}$ 형식 결합이 연결된 연속된 원자배열이다. 스핀-궤도 결합이 없는 상황에서 시간역진 대칭 그리고 반전 대칭에 의 해서 보호받는 위상 마디선 특성을 제일원리 전자구조 계산으 로 확인하였다. 밴드 구조에서 가전자대와 전도대가 서로 교차 한다. 이러한 상황은 전자가 질량 없이 매우 빠른 속도로 움직 일 수 있음을 의미한다. 격자진동 모드 계산으로 $m-C_{8}$ 결정구 조가 구조적으로 안정한 상태임을 알았다. 또한, 제일원리 분 자 동역학 계산으로 $1500 \mathrm{~K}$ 온도에서도 열적으로 안정한 구 조라는 것을 확인하였다. 외부 압력 $(60 \mathrm{GPa}$ 부근)을 가할 경 우 흑연으로부터 $m-C_{8}$ 결정구조가 만들어질 수 있음을 보였 다. $77 \mathrm{GPa}$ 이하에서는 $m-C_{8}$ 결정구조가 bco- $\mathrm{C}_{16}$ 결정구조보 다 더 안정하다.

앞서 언급하였듯이 탄소는 매우 다양한 동소체를 가지고 있 어서 실험적으로도 특정 동소체를 확인하는 것에 어려움이 있 는 경우가 있다. 특별히 많은 동소체들이 섞여져서 동시에 합 성된 탄소 샘플의 경우 다양한 결정구조들에 의한 X-선 회절 데이터가 한꺼번에 나오게 된다. $m-C_{8}$ 결정구조는 고압에서도 안정한 결정구조이다. 더욱이 $m-C_{8}$ 결정구조는 실험적으로 관 측된 폭발매연(detonation soot) 샘플의 $\mathrm{X}$-선 회절 데이터를 최근에 발표된 다른 결정구조들(IGN, $\left.T_{6}, b_{c o}-C_{16}\right)$ 보다 더 잘 설명한다.

탄소 동소체가 너무나 많기 때문에 동일한 하나의 결정구조 에 대해서 여러 편의 논문들이 발표되는 사태가 자주 발생해

\section{REFERENCES}

[25] H.-J. Sung, S. Kim, I.-H. Lee and K. J. Chang, NPG Asia Materials 9, e361 (2017) 


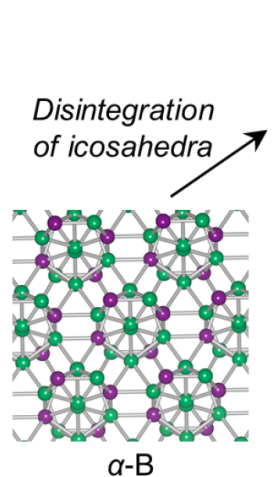

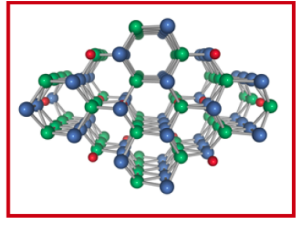

hex- $\mathrm{B}_{v}$ Intermediate phase

Phase transition under $7-20 \mathrm{GPa}$ and $1500-2500 K$

$\alpha-\mathrm{B}$

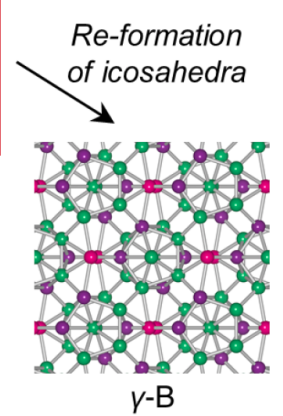

Fig. 10. Three-dimensional buckled honeycomb boron lattice with vacancies as an intermediate phase.

왔다. 이러한 문제점을 해결하기 위해서 D. M. Proserpio 교 수가 데이터베이스를 공개했다. 탄소 기반 3차원 결정구조들에 대하여 현재까지 구축된 결정구조 정보를 URL(http://sacada. sctms.ru/)을 통해서 확인할 수 있다. 2007년 5월 현재 522 개의 동소체가 등록되어 있다.

\section{준안정 결정구조 탐색: 3차원 붕소 동소체}

붕소(B)는 탄소 $(\mathrm{C})$ 와 유사하게 매우 단단한 구조를 이루고 매우 다양한 동소체를 형성한다. $\alpha-\mathrm{B}_{12}, \beta-\mathrm{B}_{106}, \gamma-\mathrm{B}_{28}$ 등 다 양한 동소체가 알려져 있다. 특이하게도 정이십면체를 형성하 는 12 개의 붕소 원자 융합체가 단위구조로서 역할을 한다. $\gamma$ $-\mathrm{B}_{28}$ 구조는 추가적으로 $\mathrm{B}_{2}$ 단위구조를 가지고 있다. 광역 최 적화 계산을 통하여 B vacancy를 가지고 있는 두 가지의 변 형된 허니콤 격자 구조들 $(C 2 / m, P 2 / / c)$ 을 찾았다. ${ }^{[26]}$ 정이십면 체 단위구조를 가지고 있는 준안정구조보다 더 유연하게 변형 될 수 있는 B vacancy를 포함하고 있는 준안정 구조들을 찾 아 낼 수 있었다. 이들 구조들은 정이십면체 단위구조를 가지 고 있지 않은 특징이 있고, 고온 고압 상태에서 B vacancy는 쉽게 움직일 수 있음을 분자동역학 계산으로 확인하였다.

그림 10에서처럼 이러한 중간 단계의 안정적인 구조들을 바 탕으로 Ostwald의 단계 규칙을 활용하면 고온 고압 상황에서 일어나는 $\alpha-\mathrm{B}_{12}$ 구조에서 $\gamma-\mathrm{B}_{28}$ 구조로의 미시적 상전이 현상 을 기술할 수 있었다. ${ }^{[26]}$ 엔탈피가 낮아서 보장되는 구조적 준 안정성 그리고 $\mathrm{B}$ vacancy를 포함하는 결정구조 특유의 구조 변이에 대한 유연성을 동시에 가지는 결정구조가 복잡한 결정 구조들 사이를 이어주는 중간단계가 될 수 있음을 확인하였다.

\section{초기능성 소재 설계/탐색: 붕소 카고메 격자}

카고메(Kagome) 격자구조는 쩔쩔맴 자기정렬, 강자성, 그리

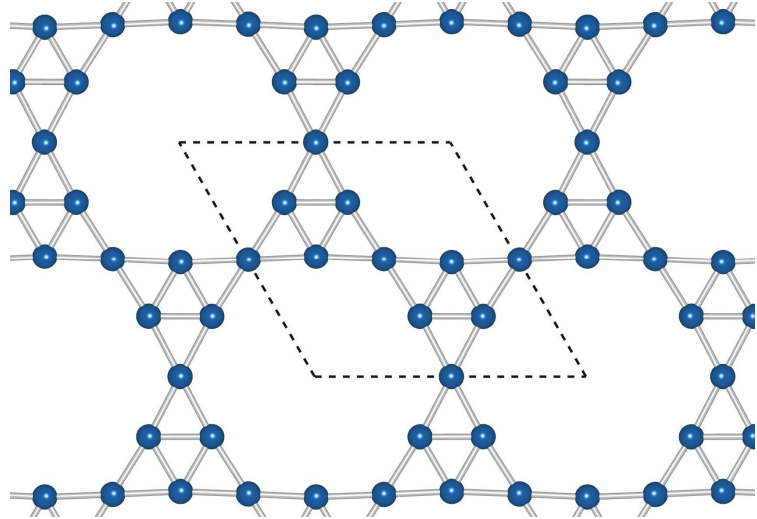

Fig. 11. A boron triangular Kagome lattices.

고 위상학적으로 특이한 구조를 제공하는 것으로 알려져 있다. 카고메 격자는 반자성 상호작용이 존재할 때 자연스럽게 쩔쩔 맴 자기정렬을 가질 수 있다. 이러한 이유로 카고메 격자는 새 로운 자성체를 설계하는 관점에서 매우 흥미로운 구조이다. 하 지만 매우 제한적인 경우에만 카고메 격자구조가 가능한 것으 로 알려져 있다. 결정구조-물성의 관계에서 구조의 안정성까지 고려하여야만 설계/탐색이 완료된다. 특히, 결정구조가 안정적 으로 형성될 수 있는 조건들은 매우 중요한 항목이며 동시에 매우 일반적인 고려가 필요한 것이다. 일반적인 방법으로 결정 성장 방식까지 최적화할 수는 없으나 몇 가지 가능한 이론적 단계를 나누어서 결정성장 아이디어들을 적용해 볼 수는 있는 상황이다.

$\mathrm{Ag}$ 금속 표면 위에서 $\mathrm{Mg}$ 원자가 손님 원자로 분포하는 상 황에서 붕소(B) 원자가 그림 11 과 같은 카고메 격자를 이룰 수 있음을 광역 최적화 방법으로 확인하였다. ${ }^{[27]}$ 붕소 카고메 격자는 페르미 준위 부근에서 위상학적으로 특이한 편평한 밴 드구조와 반금속 강자성(half-metallic ferromagnetism)을 보인 다는 사실을 밝혔다. ${ }^{[27]}$ 또한, 스핀-궤도 결합(spin-orbit coupling)이 있을 때 양자 비정상 홀 효과(quantum anomalous Hall effect)를 얻을 수 있음을 예측하였다. ${ }^{[27]}$

\section{초기능성 소재 합성을 위한 반응경로 최적화}

앞서 서론에서 언급하였듯이 초기능성 소재 설계/탐색에서 는 제일원리 전자구조 계산에 그 기초를 두고 있다. 제일원리 전자구조 계산 정밀도 내에서 이론적으로 예측한 초기능성 소

\section{REFERENCES}

[26] W. H. Han, Y. J. Oh, D.-H. Choe, S. Kim, I.-H. Lee and K. J. Chang, NPG Asia Materials 9, e400 (2017).

[27] S. Kim, W. H. Han, I.-H. Lee and K. J. Chang, Sci. Rep. 7, 7279 (2017) 
재들이 실험적으로 합성되고 정량적 초기능성을 보여줄 가능성 이 있다. 첫째 조건으로 예측된 결정구조가 열역학적으로 안정 해야만 한다. 왜냐하면, 결정구조 안정성은 결정구조가 가지는 에너지에 따라서 볼츠만 분포를 따른다고 볼 수 있기 때문이 다. 물론, 압력, 화학 조성비 등을 바꾸어서 예측한 결정구조가 열역학적으로 가장 안정할 수 있으면 더욱 좋을 것이다. 한 발 더 나아가서 실현 가능성이 높은 특별한 합성 화학반응 경로 를 이론적으로 제시할 수 있으면 이상적일 것이다.

초기의 원자 무리들로부터 말기의 원자 무리들로 이어지는 일반적인 화학반응 경로를 이론적으로 계산하는 것은 매우 도 전적인 계산이다. 주어진 온도에서 확률적으로 실현 가능성이 가장 높은 초기와 말기를 연결하는 화학 반응경로는 OnsagerMachlup 작용(action)을 최소화하는 것이다. ${ }^{[2]}$ 화학 반응경로 들 중에서 가장 실현 가능성이 높은 반응경로를 구해낼 수 있 는 방법으로 최근 Action-CSA 방법을 제안하였다. ${ }^{[29]}$ 작용을 광역적으로 최소화할 수 있는 화학반응 경로를 무수히 많고 다양한 화학 반응경로들 중에서 뽑아낼 수 있다. 앞서 언급한 $\mathrm{CSA}$ 방법을 그대로 적용하여 작용 광역 최적화를 이룰 수 있 다. 즉, 최소 작용값을 주는 경로를 적극적으로 찾아내는 것이 다.

다양한 반응경로들을 찾아내는 새로운 프로토콜 Action-CSA 가 보다 많은 화학반응 문제 풀이에 동원될 수 있을 것이다. 아울러, Action-CSA 방법이 초기능성 소재 설계/탐색 분야와 연계되어 시너지를 창출할 수 있을 것으로 판단한다.

\section{나오는 글}

본 해설에서는 제일원리 전자구조 계산에 바탕을 둔 소재 설
계/탐색 연구의 방법과 응용연구 사례를 살펴보았다. 특별히, 광역 최적화 방법과 제일원리 전자구조 계산 방법을 결합하면 초기능성 소재 설계/탐색이 초고도 병렬계산 방식으로 가속화 될 수 있다는 것을 제안하였다.

실리콘 태양전지 소재, 탄소 발광다이오드 소재, 탄소 위상 소재를 이론적으로 설계/탐색할 수 있음을 보였다. 아울러 3차 원 붕소 동소체들 사이의 미시적 변형 기작과 반금속 강자성을 가지는 2 차원 붕소 카고메 격자 구조를 제안할 수 있었다. 이러 한 응용 연구 사례들로부터 개발된 광역 최적화 방법과 제일원 리 전자구조 계산 방법의 체계적인 결합은 신소재 설계/탐색을 위한 보편적 선행 필요조건이 될 수 있음을 보였다.

제일원리 전자구조 계산을 통한 초기능성 소재의 설계/탐색 연구 분야는 밝은 미래를 가지고 있다. 보다 더 많은 새로운 아 이디어들이 개발된 프로토콜에 곧바로 적용될 수 있기 때문이 다. 개발된 프로토콜은 계산자원에 대한 확실한 확장성을 가지 고 있기 때문에 향후 상상하기 힘들 정도의 초고도 병렬계산이 새로운 아이디어 구현을 도와 줄 수 있을 것이다. 또한, 보다 더 큰 단위셀을 동원하는 초기능성 소재의 설계/탐색은 더욱더 좋은 성능지수를 가지는 초기능성 소재의 발굴에 기여할 것으 로 판단된다.

설계/탐색된 초기능성 소재들이 빠른 시간 안에 합성되고 응 용되어서 '소재 설계-응용' 시간주기를 10년 미만 수준으로 앞 당기는 사례들이 다수 나오길 희망한다.

\section{REFERENCES}

[28] L. Onsager and S. Machlup, Phys. Rev. B 91, 1505 (1953).

[29] J. Lee, I.-H. Lee, I. Joung, J. Lee and B. R. Brooks, Nat. Commun. 8, 15443 (2017). 